\title{
CONVERGENCE OF FOURIER SERIES SOLUTIONS IN THE EIASTIC ANALYSES OF THE SHEAR WALLS SUB- JECTED TO THE VARIOUS EXTERNAI PLANE FORCES
}

\author{
by IKUO TOKUHIRO* Member of A.I.J.
}

\section{Introduction}

A series of the elastic analysis of the shear walls by Airy's stress function have been reported ${ }^{1) \sim 3}$ by Dr. M. Tomii and the author. These were analysed by using the stress function which consists of the series and the polynomials. The stresses, displacements, etc. were expanded into the Fourier series, and then these values are approximated. In this paper, before the applications of these analyses, the accuracy of the calcurated values of the stresses, displacements, etc. is examined.

The quarter part $(x \geqq 0, y \geqq 0)$ of each shear wall subjected to the fundamental plane forces and moments :

I. which are antimetric with regard to the longitudinal and transversal center lines of the shear walls,

II. which are symmetric with regard to the longitudinal and transversal center lines of the shear walls,

III. which are antimetric with regard to the longitudinal center line and symmetric to the transversal center line of the shear wall,

were analysed.

These shear walls were called shear wall I, II, and III.

The author shows the continuity conditions between the wall and frame as follows. There are four elements which have satisfied their continuity conditions on each boundary between the wall and beam, and the wall and column. These are the shearing force, thenormal force, the unit elongation parallel to the boundary, and the normal displacement. Two (shearing force, normal displacement) of the four elements on the boundaries of the wall were given to the frame, and the remaining two elements (normal force, unit elongation parallel to the boundary) on the boundaries of the frame were derived, and the two equations for the continuity conditions of the remaining two elements were made on the boundaries. These equations were derived in such a way as to develop each element on the wall and frame into the Fourier series. As these two equations are taken into account by the limited number $\left(r_{m}, r_{n}\right)$ of terms of the Fourier series, the continuity conditions are not precicely satisfied.

In this paper, the author shows the relations between the convergence and the number of terms of the Fourier series in the analyses of the shear wall I, and II.

The definitions of the shear wall (see Fig. 5.1) in this paper are the same as the shear walls which were used in the numerical examples in the previous papers ${ }^{1)}{ }^{3)}$. The stress distributions in the wall and frame, and the displacements of the shear wall have been reported in the previous papers ${ }^{1 \sim^{3}}$.

$\$ 5.1$ The convergence and the number of the terms of the Fourier series in the analysis of the shear wall (see Fig. 5.2) loaded antimetrically with regard to $x$-axis and $y$ axis respectively

The continuity conditions on the boundaries between the wall and frame

* Associate Prof. of Kyushu Institute of Design 
A. By expanding the normal force $\left.t \sigma_{y}\right|_{y=b}$ of the wall, and that $w_{a_{1}}$ of the beam in the Fourier series with regard to $\sin \xi_{m}\left(\xi_{m}=m \pi / 2 a \cdot x\right)$ :

$$
\begin{aligned}
\left.t \sigma_{y}\right|_{y=b} & \doteqdot t \sum_{m=1,3,5, \ldots} \sigma_{y m} \sin \xi_{m} . \\
w_{a_{1}} & \doteqdot \\
m=1,3,5, \ldots & w_{a_{1} m} \sin \xi_{m}
\end{aligned}
$$

and making the right side of eq. 5.1 a equal to that of eq. $5.2 \mathrm{a}, r_{m}$ (number of $m=1,3,5, \cdots$ ) equations for the continuity of the normal stresses (per unit length) on the boundary between the wall and beam are obtained as follows:

$$
\left.t \sigma_{y m}=w_{a_{1} m} \text { (for each } m=1,3,5, \cdots\right)
$$

B. By expanding the normal force $\left.t \sigma_{x}\right|_{x=a}$ of the wall, and that $w_{b 1}$ of the column in the Fourier series with regard to $\sin \eta_{n}\left(\eta_{n}=n \pi / 2 b \cdot y\right)$ :

$$
\begin{aligned}
\left.t \sigma_{x}\right|_{x=a} & \doteqdot t \sum_{n=1,3,5, \ldots} \sigma_{x n} \sin \eta_{n} . \\
w_{b 1} & \doteqdot \sum_{n=1,3,5, \ldots} w_{b_{1} n} \sin \eta_{n}
\end{aligned}
$$

and making the right side of eq. $5.1 \mathrm{~b}$ equal to that of eq. $5.2 \mathrm{~b}, r_{n}$ (number of $n=1,3,5, \cdots$ ) equations for the continuity of the normal stresses (per unit length) on the boundary between the wall and column are obtained as follows:

$$
t \sigma_{x n}=w_{b_{1 n}} \text { (for each } n=1,3,5, \cdots \text { ) }
$$

C. By expanding the unit elongation $\left.\varepsilon_{x}\right|_{y=b}$ of the wall, and that $\varepsilon_{a_{1}}$ of the beam in the Fourier series with regard to $\sin \xi_{m}$ :

$$
\begin{aligned}
\left.\varepsilon_{x}\right|_{y=b} \doteqdot \sum_{m=1,3,5, \ldots} \varepsilon_{x m} \sin \xi_{m} \\
\varepsilon_{a_{1}} \doteqdot \sum_{m=1,3,5, \ldots} \varepsilon_{a_{1 m}} \sin \xi_{m}
\end{aligned}
$$

and making the right side of eq. $5.3 \mathrm{a}$ equal to that of eq. $5.4 \mathrm{a}, r_{m}$ equations for the continuity of the unit elongations are obtained as follows :

$$
\varepsilon_{x m}=\varepsilon_{a 1 m} \text { (for each } m=1,3,5, \cdots \text { ) }
$$

D. By expanding the unit elongation $\left.\varepsilon_{y}\right|_{x=a}$ of the wall, and that $\varepsilon_{b_{1}}$ of the column in the Fourier series with regard to $\sin \eta_{n}$ :

$$
\begin{aligned}
&\left.\varepsilon_{y}\right|_{x=a} \doteqdot \sum_{n=1,3,5, \ldots} \varepsilon_{y n} \sin \eta_{n} . \\
& \varepsilon_{b 1} \doteqdot \sum_{n=1,3,5, \ldots} \varepsilon_{b_{1 n}} \sin \eta_{n}
\end{aligned}
$$

and making the right side of eq. $5.4 \mathrm{~b}$ equal to that of eq. $5.5 \mathrm{~b}, r_{n}$ equations for the continuity of the unit elongations parallel to and on the boundary between the wall and column are obtained as follows :

$$
\varepsilon_{y n}=\varepsilon_{b 1 n}(\text { for each } n=1,3,5, \cdots)
$$

The continuity condition diagrams of the normal stresses (each left side of eqs. $5.1 \mathrm{a}, 5.1 \mathrm{~b}, 5.2 \mathrm{a}$,
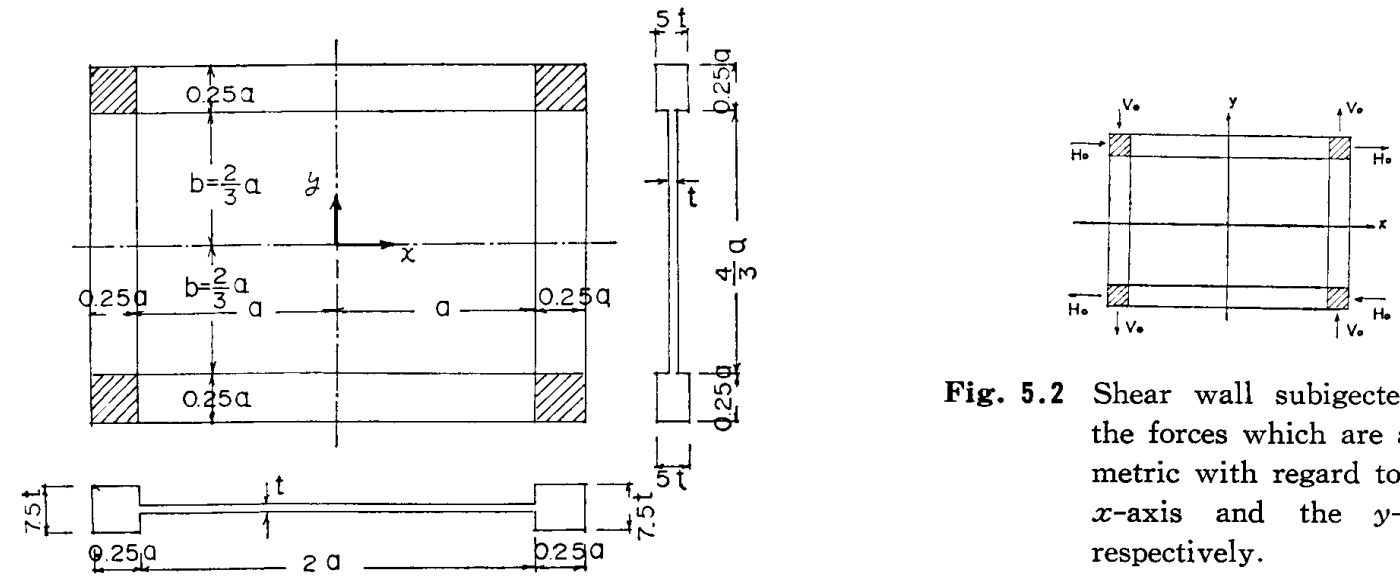

Fig. 5.2 Shear wall subigected to the forces which are antimetric with regard to the $x$-axis and the $y$-axis respectively.

Fig. 5.1 Definitions of shear wall 
$5.2 \mathrm{~b})$ are shown in Figs. $5.3 \mathrm{a}, 5.4 \mathrm{a}, 5.5 \mathrm{a}$ for the three numbers $\left(r_{m}=r_{n}=5,20,45\right)$ of the terms of the Fourier series, and those of the unit elongations (each left side of eqs. $5.4 \mathrm{a}, 5.4 \mathrm{~b}, 5.5 \mathrm{a}, 5.5 \mathrm{~b}$ ) are shown in Figs. $5.3 \mathrm{~b}, 5.4 \mathrm{~b}, 5.5 \mathrm{~b}$ for the three numbers $\left(r_{m}=r_{n}=5,20,45\right)$ of the Fourier series.

The errors by the partial sum in the Fourier expantion are derived from the Bessel's inequality as follows :

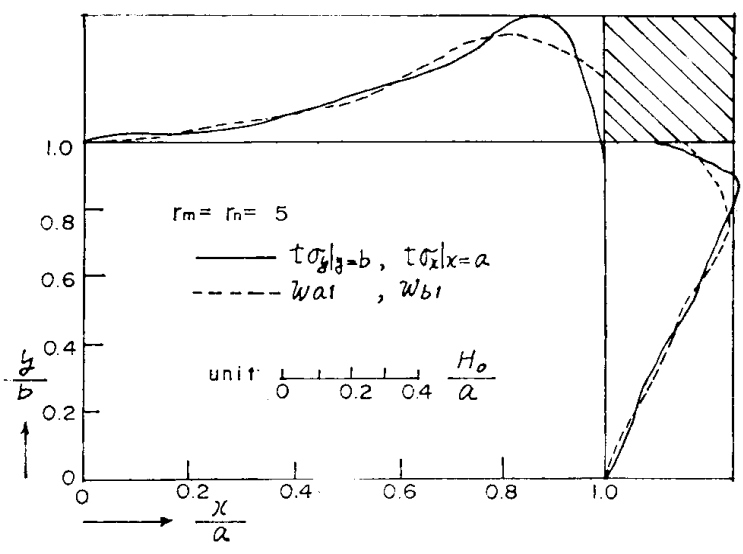

Fig. 5.3 a Continuity conditions of the normal stresses (per unit length) on the boundaries between the wall and frame $\left(r_{m}, r_{n}=5\right)$

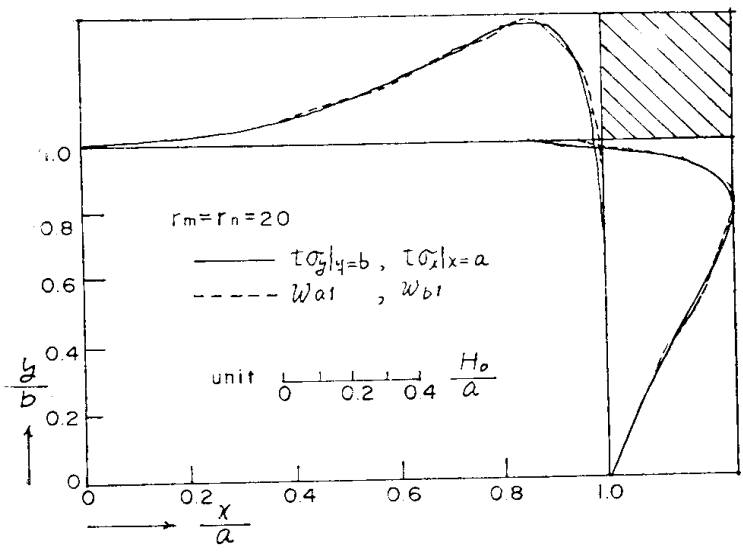

Fig. 5.4 a Continuity condtitions of the narmal stresses (per unit length) on the boundaries between the wall and frame $\left(r_{m}, r_{n}=20\right)$

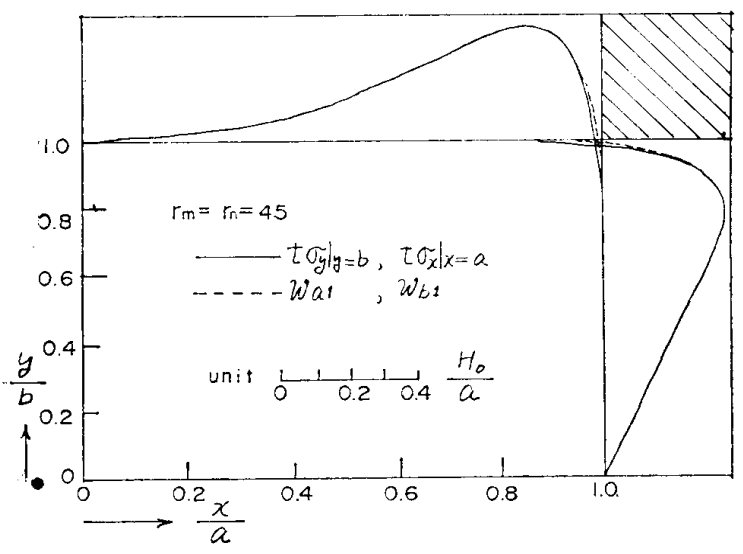

Fig. 5.5 a Continuity conditions of the normal stresses (per unit length) on the boundaries between the wall and frame $\left(r_{m}, r_{n}=45\right)$

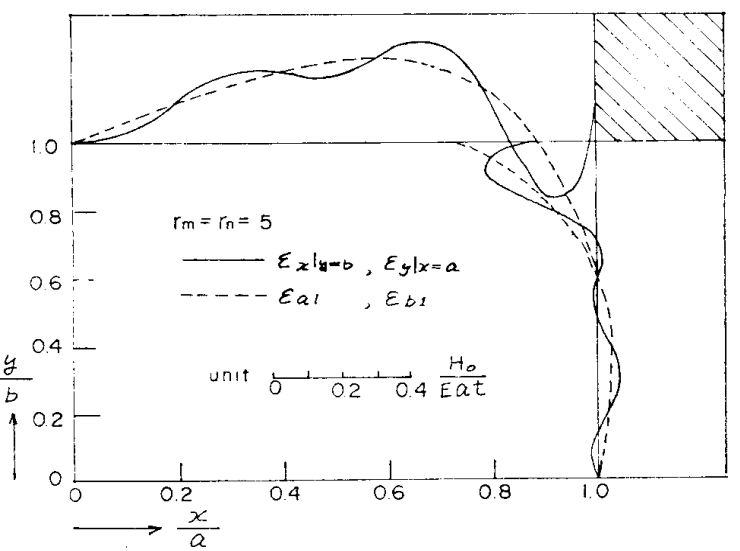

Fig. 5.3 b Condinuity conditions of the unit elongations parallel to and on the boundories between the wall and frame $\left(r_{m}, r_{n}=5\right)$

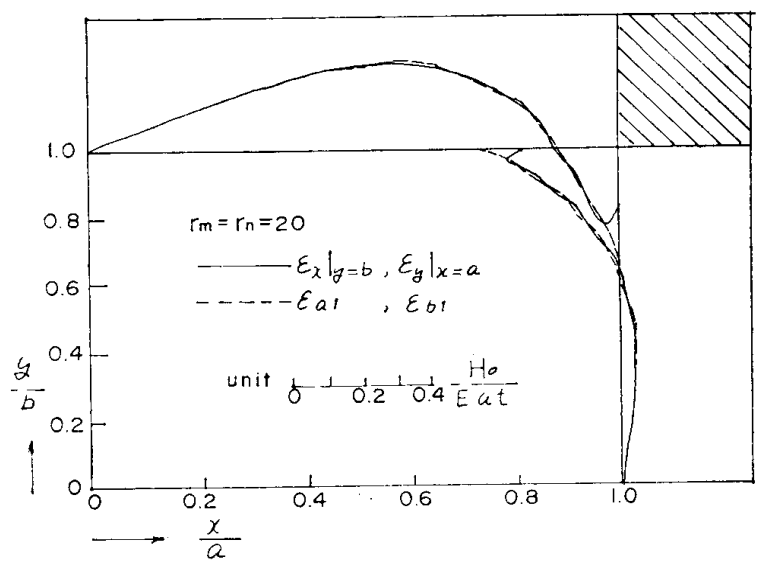

Fig. 5.4 b Continuity conditions of the unit elongations parallel to and on the boundaries between the wall and frame $\left(r_{m}, r_{n}=20\right)$

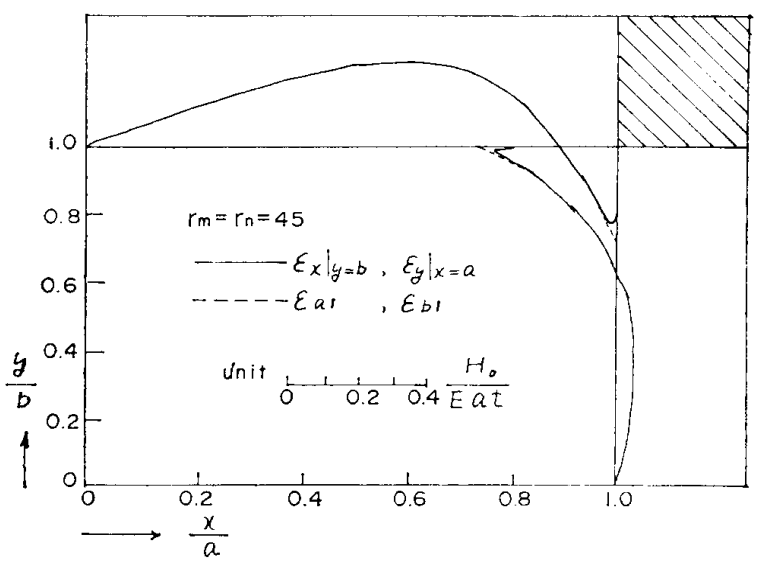

Fig. 5.5 b Continuity conditions of the unit elongations parallel to and on the boudaries between the wall and frame $\left(r_{m}, r_{n}=45\right)$ 
$\Phi=\frac{\sum_{m}^{2 r_{m}-1}\left(t \sigma_{y m}\right)^{2}}{\frac{2}{a} \int_{0}^{a}\left(t \sigma_{y \mid y=b}\right)^{2} d x}<1$ (for eq. $\left.5.1 \mathrm{a}\right)$

$\Phi=\frac{\sum_{m}^{2 r_{m}-1}\left(w_{a_{1} m}\right)^{2}}{\frac{2}{a} \int_{0}^{a}\left(w_{a_{1}}\right)^{2} d x}<1$ (for eq. $\left.5.2 \mathrm{a}\right)$

$\Phi=\frac{\sum_{n}^{2 r_{n}-1}\left(t \sigma_{x n}\right)^{2}}{\frac{2}{b} \int_{0}^{b}\left(\left.t \sigma_{x}\right|_{x=a}\right)^{2} d y}<1$ (for eq. $5.1 \mathrm{~b}$ )

$\Phi=\frac{\sum_{n}^{2 r_{n}-1}\left(w_{b 1 n}\right)^{2}}{\frac{2}{b} \int_{0}^{b}\left(w_{b 1}\right)^{2} d y}<1$ (for eq. $5.2 \mathrm{~b}$ )

$\Phi=\frac{\sum_{m}^{2 r_{m}-1}\left(\varepsilon_{x m}\right)^{2}}{\frac{2}{a} \int_{0}^{a}\left(\varepsilon_{x \mid y=b}\right)^{2} d x}<1$ (for eq. $\left.5.4 \mathrm{a}\right)$

$\Phi=\frac{\sum_{m}^{2 r_{m}-1}\left(\varepsilon_{a 1 m}\right)^{2}}{\frac{2}{a} \int_{0}^{a}\left(\varepsilon_{a 1}\right)^{2} d x}<1$ (for eq. $5.5 \mathrm{a}$ )

$\Phi=\frac{\sum_{n}^{2 r_{n-1}}\left(\varepsilon_{y n}\right)^{2}}{\frac{2}{b} \int_{0}^{b}\left(\left.\varepsilon_{y}\right|_{x=a}\right)^{2} d y}<1$ (for eq. 5.4 b)

$\Phi=\frac{\sum_{n}^{2 r_{n}-1}\left(\varepsilon_{b_{1 n}}\right)^{2}}{\frac{2}{b} \int_{0}^{b}\left(\varepsilon_{b_{1}}\right)^{2} d y}<1$ (for eq. $\left.5.5 \mathrm{~b}\right)$

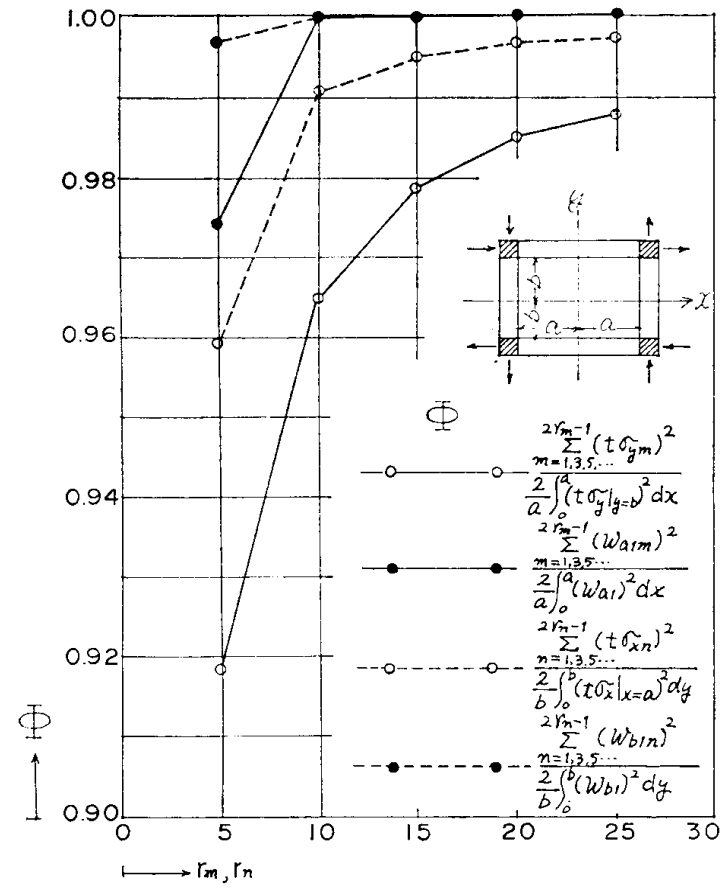

Fig. 5.6 a Convergence of the means of the squares of the errors by expanding the normal stresses(per unit length) on the boundaries between the wall and frame into the Fourier series

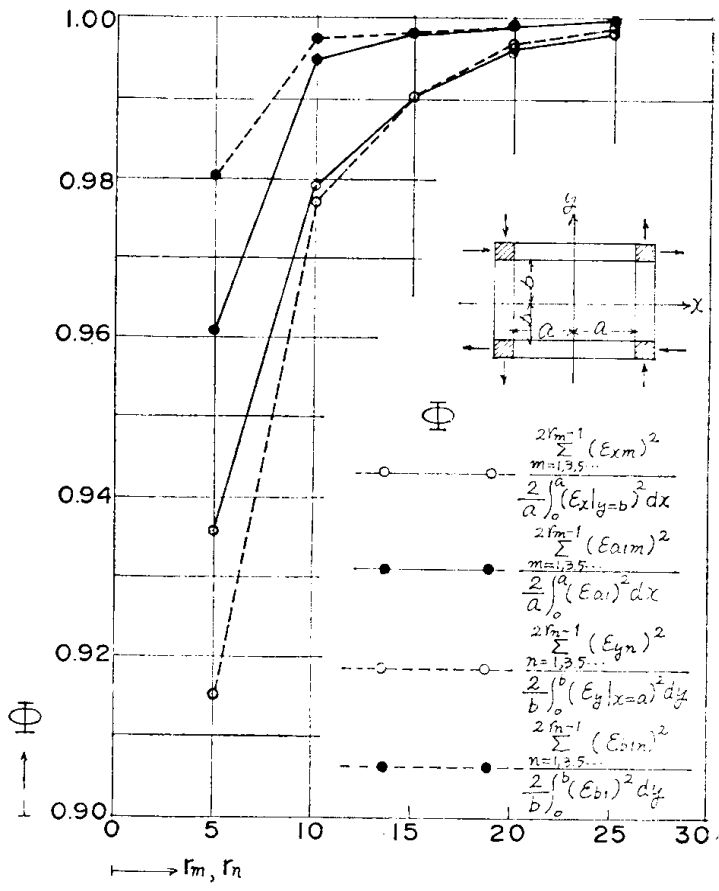

Fig. 5.6 b Convergence of the means of the squares of the errors by expanding the unit elongations parallel to and on the boundaries between the wall and frame into the Fourier series 


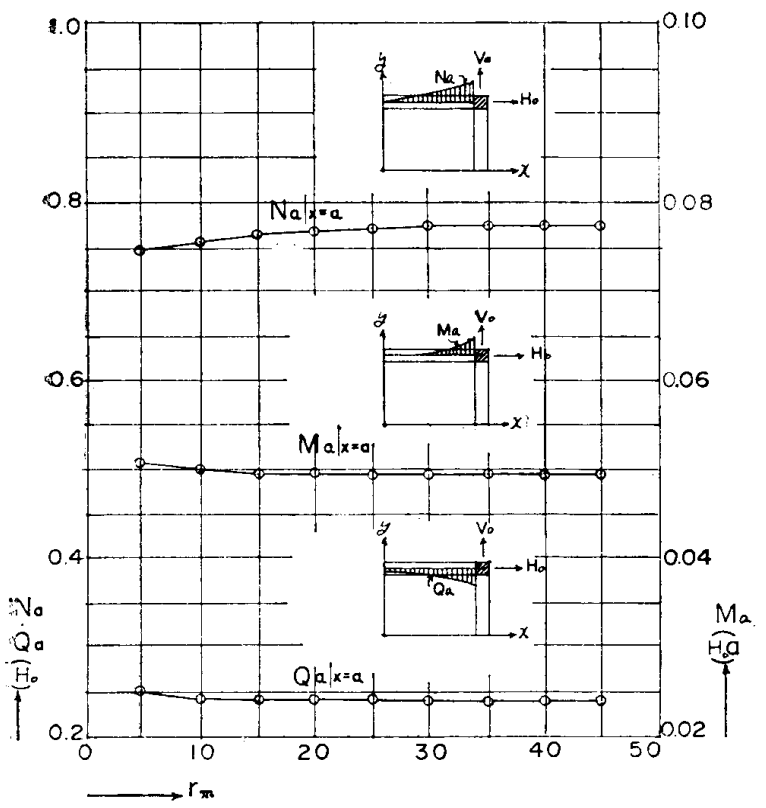

Fig. 5.7 a Convergence and number of the terms of the Fourier series with respect to the bending moment $\left.M_{a}\right|_{x=a}$, the shearing force $\left.\mathrm{Q}_{a}\right|_{x=a}$, the axial tensile force $\left.N_{a}\right|_{x=a}$ in the beam

The ratioes $\phi$ in eqs. $5.7 \mathrm{a} \sim 5.10 \mathrm{~b}$ are shown in Figs. $5.6 \mathrm{a}, 5.6 \mathrm{~b}$.

The conditions of the convergence with regard to the bending moment $M_{a}$, shearing force $Q_{a}$, and axial force $N_{a}$ of the beam are shown in Fig. 5.7 a, and those with regard to the bending moment $M_{b}$, shearing force $Q_{b}$, and the axial force $N_{b}$, of the column are shown in Fig. $5.7 \mathrm{~b}$.

In Fig. 5.8, the conditions of the convergence with regard to the displacements at the corner of the frame are shown.

\section{$\$ 5.2$ The convergence and the number of the terms of the Fourier series in the analysis of the shear wall (see}

Fig. 5.9) loaded symmetrically with regard to the $x$-axis and $y$-axis respectively

The continuity conditions on the boundaries between the wall and frame

A. By expanding the normal force $\left.t \sigma_{y}\right|_{y=b}$ of the wall, and that $w_{a_{1}}$ of the beam in the Fourier series with regard to $\cos \xi_{m}\left(\xi_{m}=m \pi / 2 \mathrm{a} \cdot x\right)$ :

$$
\begin{aligned}
\left.t \sigma_{y}\right|_{y=b} & \doteqdot t \sum_{m=2,4,6, \ldots} \sigma_{y m} \cos \xi_{m}+t \sigma_{y 0} \\
w_{a_{1}} & \doteqdot \sum_{m=2,4,6, \ldots} w_{a_{1} m} \cos \xi_{m}+w_{a_{10}}
\end{aligned}
$$

and making the right side of eq. 5.11 a equal to that of eq. $5.12 \mathrm{a}, r_{m}$ (number of $m=2,4,6, \cdots$ ) +1 equations for the continuity of the normal stresses (per unit length) on the boundary between the wall beam are obtained as follows:

$$
t \sigma_{y m}=w_{a 1 m} \text { (for each } m=2,4,6, \cdots \text { ) and } t \sigma_{y_{0}}=w_{a_{10}}
$$

B. By expanding the normal force $\left.t \sigma_{x}\right|_{x=a}$ of the wall, and that $w_{b_{1}}$ of the column in the Fourier series with regard to $\cos \eta_{n}\left(\eta_{n}=n \pi / 2 b \cdot y\right)$ :

$$
\left.t \sigma_{x}\right|_{x=a} \doteqdot t \sum_{n=2,4,6, \ldots} \sigma_{x n} \cos \eta_{n}+t \sigma_{x 0} \cdots
$$




$$
w_{b_{1}} \doteqdot \sum_{n=2,4,6, \ldots} w_{b 1 n} \cos \eta_{n}+w_{b 10}
$$

and making the right side of eq. $5.11 \mathrm{~b}$ equal to that of eq. $5.12 \mathrm{~b}, r_{n}$ (number of $\left.n=2,4,6, \cdots\right)+\mathrm{I}$ equations for the continuity of the normal stresses (per unit length) on the boundary between the wall and column are obtained as follows :

$$
t \sigma_{x n}=w_{b 1 n} \text { (for each } \mathrm{n}=2,4,6, \cdots \text { ) and } t \sigma_{x 0}+w_{b_{10}}
$$

C. By expanding the unit elongations $\left.\varepsilon_{x}\right|_{y=b}$ of the wall, and that $\varepsilon_{a_{1}}$ of the beam in the Fourier series with regard to $\cos \xi_{m}$ :

$$
\begin{aligned}
\left.\varepsilon_{x}\right|_{y=b} \doteqdot \sum_{m=2,4,6, \cdots} & \varepsilon_{x m} \cos \xi_{m}+\varepsilon_{x 0} \\
\varepsilon_{a 1} & \doteqdot \sum_{m=2,4,6, \cdots} \varepsilon_{a 1 m} \cos \xi_{m}+\varepsilon_{a 10}
\end{aligned}
$$

and making the right side of eq. $5.13 \mathrm{a}$ equal to that of eq. $5.14 \mathrm{a}, r_{m}$ equations for the continuity of the unit elongations are obtained as follows.

$$
\varepsilon_{x m}=\varepsilon_{a 1 m} \text { (for each } m=2,4,6, \cdots \text { ) and } \varepsilon_{x 0}=\varepsilon_{a 10}
$$

D. By expanding the unit elongation $\left.\varepsilon_{y}\right|_{x=a}$ of the wall, and that $\varepsilon_{b 1}$ of the column in the Fourier series with regard to $\cos \eta_{n}$ :

$$
\begin{aligned}
\left.\varepsilon_{y}\right|_{x=a} \doteqdot \sum_{n=2,4,6, \ldots} \varepsilon_{y_{n}} \cos \eta_{n}+\varepsilon_{y_{0}} \cdots \\
\varepsilon_{b_{1}} \doteqdot \sum_{n=2,4,6, \ldots} \varepsilon_{b_{1} n} \cos \eta_{n}+\varepsilon_{b_{10}}
\end{aligned}
$$

and making the right side of eq. $5.14 \mathrm{~b}$ equal to that of eq. $5.15 \mathrm{~b}, r_{n}$ equations for the continuity of the unit elongations parallel to and on the boundary between the wall and column are obtained as. follows.

$$
\varepsilon_{y n}=\varepsilon_{b 1 n} \text { (for each } n=2,4,6, \cdots \text { ) and } \varepsilon_{y 0}=\varepsilon_{b 10}
$$

The continuity condition diagrams of the normal stresses (each left side of eqs. $5.11 \mathrm{a}, 5.11 \mathrm{~b}$, $5.12 \mathrm{a}, 5.12 \mathrm{~b})$ are shown in Figs. $5.10 \mathrm{a}, 5.11 \mathrm{a}, 5.12 \mathrm{a}$ for the three numbers $\left(r_{m}=r_{n}=5,20,45\right)$ of the terms of the Fourier series, and those of the unit elongations (each left side of eqs. $5.14 \mathrm{a}, 5.14 \mathrm{~b}, 5.15 \mathrm{a}$, $5.15 \mathrm{~b}$ ) are shown in Figs. $5.10 \mathrm{~b}, 5.11 \mathrm{~b}, 5.12 \mathrm{~b}$ for the three numbers $\left(r_{m}=r_{n}=5,20,45\right)$ of the Fourier series.

The errors by the partial sum in the Fourier expantion are derived from the Bessel's inequality as follows:

$$
\left.\Phi=\frac{2\left(t \sigma_{y 0}\right)^{2}+\sum_{m}^{2 r_{m}}\left(t \sigma_{y m}\right)^{2}}{\frac{2}{a} \int_{0}^{a}\left(\left.t \sigma_{y}\right|_{y=b}\right)^{2} d x}<1 \text { (for eq. } 5.11 \mathrm{a}\right)
$$

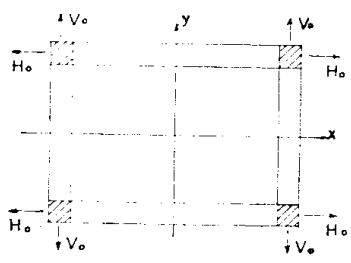

Fig. 5.9 Shear wall subjected to the forces. which are symmetric with regard to the $x$-axis and the $y$-axis. respectively

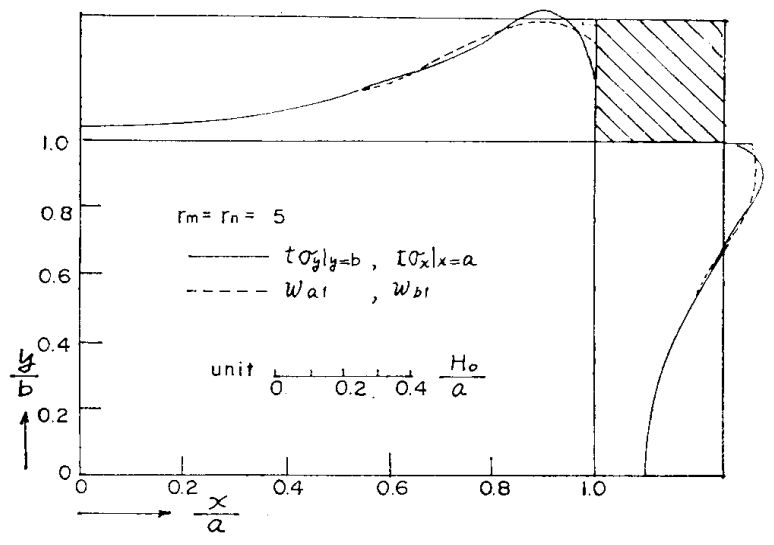

Fig. 5.10 a Continuity conditions of the normal stresses (per unit length) on the boundaries between the wall and frame $\left(r_{m}, r_{n}=5\right)$

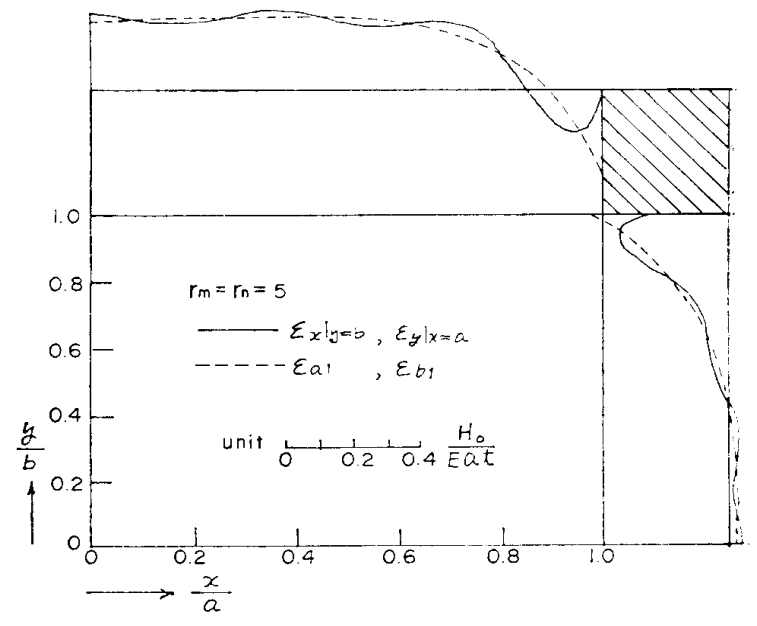

Fig. $5.10 \mathrm{~b}$ Continuity conditions of the unit elongat tions parallel to and on the boundariesbetween the wall and frame $\left(r_{m}, r_{n}=5\right.$, 


$$
\begin{aligned}
& \left.\Phi=\frac{2\left(w_{a 10}\right)^{2}+\sum_{m}^{2 r_{m}}\left(w_{a 1 m}\right)^{2}}{\frac{2}{a} \int_{0}^{a}\left(w_{a_{1}}\right)^{2} d x}<1 \text { (for eq. } 5.12 \mathrm{a}\right) \\
& \left.\Phi=\frac{2\left(t \sigma_{x 0}\right)^{2}+\sum_{n}^{2 r_{n}}\left(t \sigma_{x n}\right)^{2}}{\frac{2}{b} \int_{0}^{b}\left(\left.t \sigma_{x}\right|_{x=a}\right)^{2} d x}<1 \text { (for eq. } 5.11 \mathrm{~b}\right) \\
& \left.\Phi=\frac{2\left(w_{b_{10}}\right)^{2}+\sum_{n}^{2 r_{n}}\left(w_{b 1 n}\right)^{2}}{\frac{2}{b} \int_{0}^{b}\left(w_{b 1}\right)^{2} d y}<1 \text { (for eq. } 5.12 \mathrm{~b}\right) \\
& \left.\Phi=\frac{2\left(\varepsilon_{x 0}\right)^{2}+\sum_{m}^{2 r_{m}}\left(\varepsilon_{x m}\right)^{2}}{\frac{2}{a} \int_{0}^{a}\left(\left.\varepsilon_{x}\right|_{y=b}\right)^{2} d x}<1 \text { (for eq. } 5.14 \mathrm{a}\right) \cdots . . \\
& \left.\Phi=\frac{2\left(\varepsilon_{a 10}\right)^{2}+\sum_{m}^{2 r_{m}}\left(\varepsilon_{a 1 m}\right)^{2}}{\frac{2}{a} \int_{0}^{a}\left(\varepsilon_{a 1}\right)^{2} d x}<1 \text { (for eq. } 5.15 \mathrm{a}\right) \cdots \\
& \left.\Phi=\frac{2\left(\varepsilon_{y 0}\right)^{2}+\sum_{n}^{2 r_{n}}\left(\varepsilon_{y n}\right)^{2}}{\frac{2}{b} \int_{0}^{b}\left(\left.\varepsilon_{y}\right|_{x=a}\right)^{2} d y}<1 \text { (for eq. } 5.14 \mathrm{~b}\right) \cdots \ldots
\end{aligned}
$$

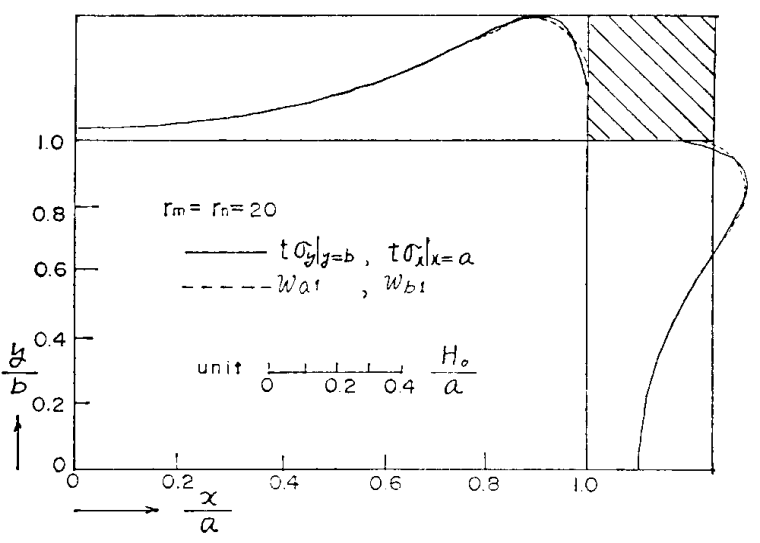

Fig. 5.11 a Continuity conditons of the normal stresses (per unit length) on the boundaries between the wall and frame $\left(r_{m}, r_{n}=20\right)$

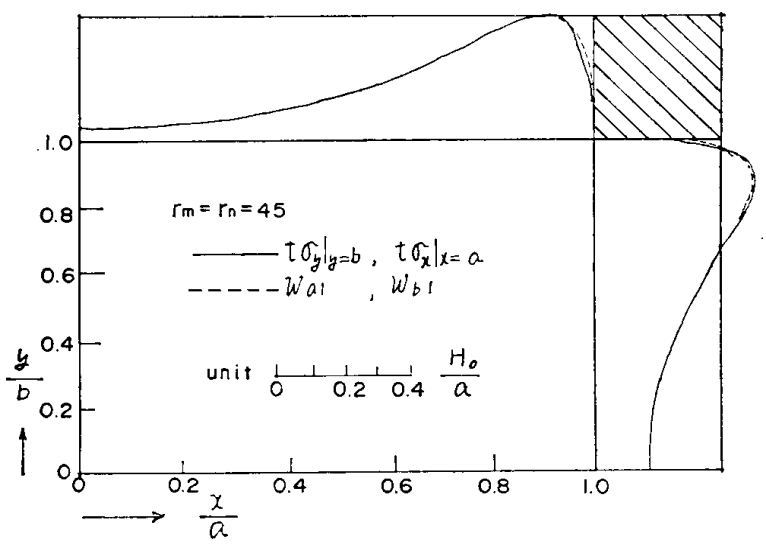

Fig. $5.12 \mathrm{a}$ Continuity conditions of the normal stresses (per unit length) on the boundaries between the wall and frame $\left(r_{m}, r_{n}=45\right)$

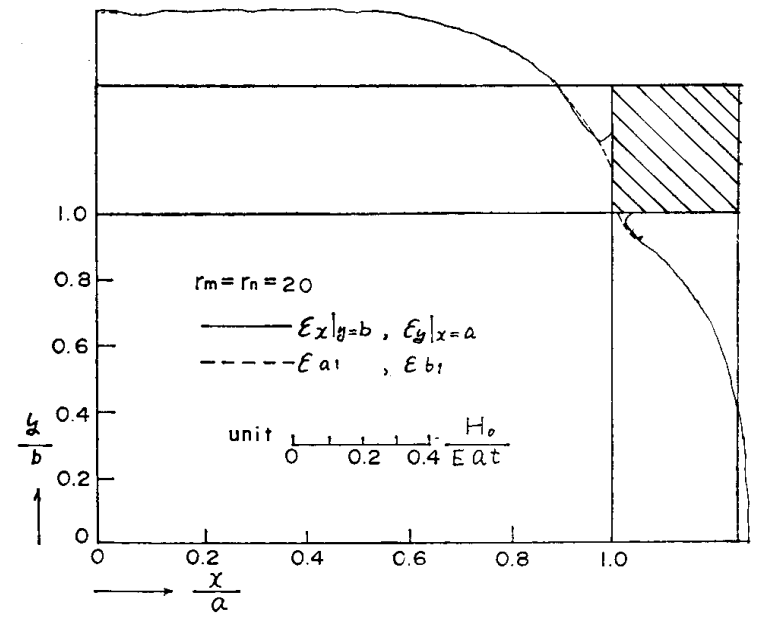

Fig. 5.11 b Continuity conditions of the unit elongations parallel to and on the boundaries between the wall and frame $\left(r_{m}, r_{n}=20\right)$

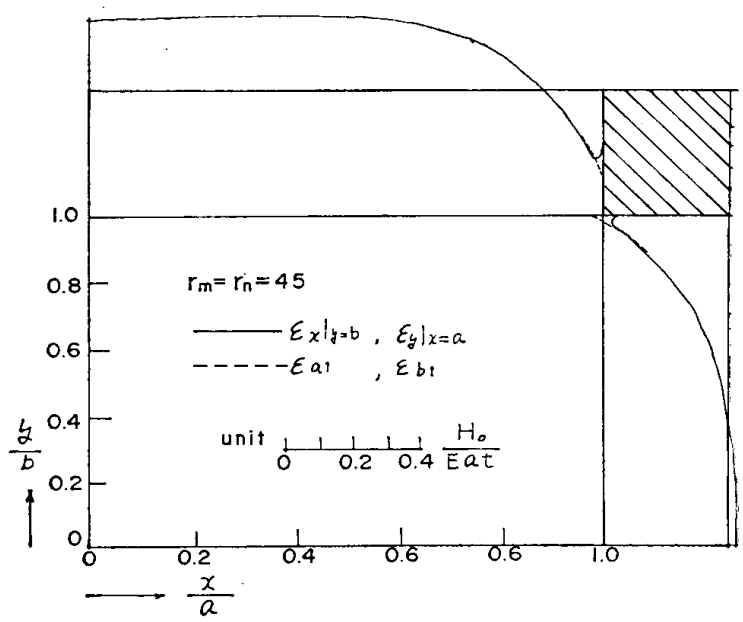

Fig. $5.12 \mathrm{~b}$ Continuity conditions of the unit elongationf parallel to and on the boundaries between the wall and frame $\left(r_{m}, r_{n}=45\right)$ 


$$
\Phi=\frac{2\left(\varepsilon_{b 10}\right)^{2}+\sum_{n}^{2 r_{n}}\left(\varepsilon_{b 1 n}\right)^{2}}{\frac{2}{b} \int_{0}^{b}\left(\varepsilon_{b 1}\right)^{2} d y}<1 \text { (for eq. } 5.15 \text { b) }
$$

The ratioes $\Phi$ in eqs. $5.17 \mathrm{a} 5.20 \mathrm{~b}$ are shown in Figs. $5.13 \mathrm{a}, 5.13 \mathrm{~b}$.

The conditions of the convergence with regard to the bending moment $M_{a}$, the shearing force $Q_{a}$, and the axial force $N_{a}$ of the beam are shown in Fig. 5.14 a, and those with regard to the bending moment $M_{b}$, the shearing force $Q_{b}$, and axial force $N_{b}$ of the column are shown in Fig. 5.14 b.

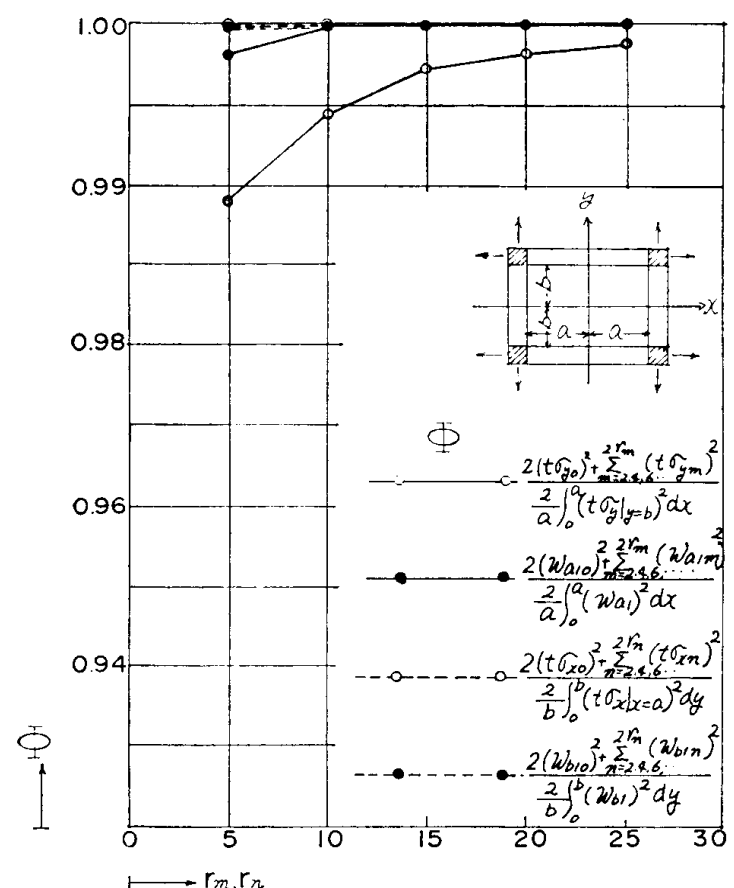

Fig. 5.13 a Convergence of the means of the squares of the errors by expanding the normal stresses (per unit length) the between the wall and frame into on the boundaries Fourier series
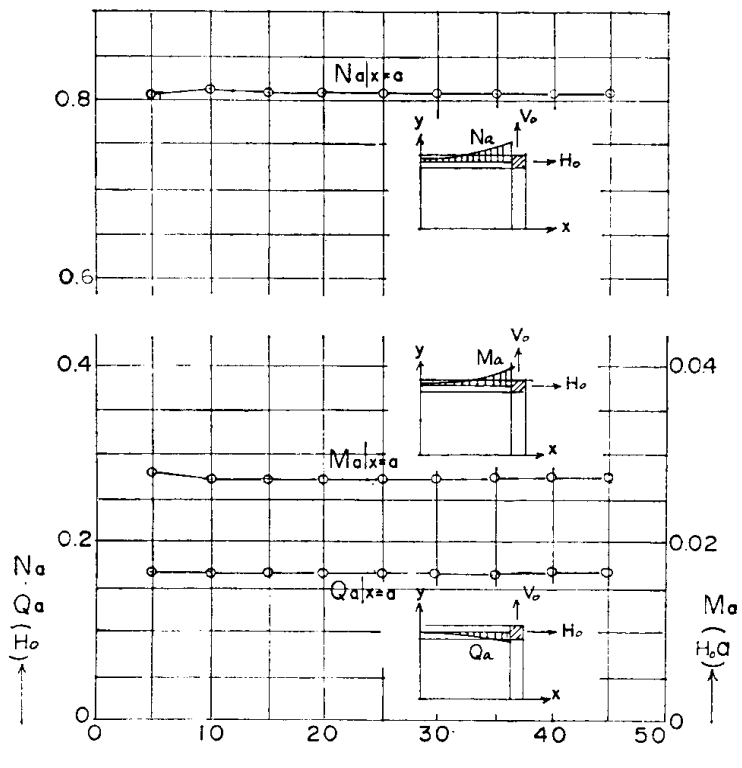

Fig. 5.14 a Convergence and number of the terms of the Fourier series with respect to the bending moment $\left.M_{a}\right|_{x=a}$, the shearing force $\left.Q_{a}\right|_{x=a}$, the axial tensile force $\left.N_{a}\right|_{x=a}$, the shearing force $\left.Q_{a}\right|_{x=a}$, the axial tensile force $\left.N_{a}\right|_{x=a}$, in the beam

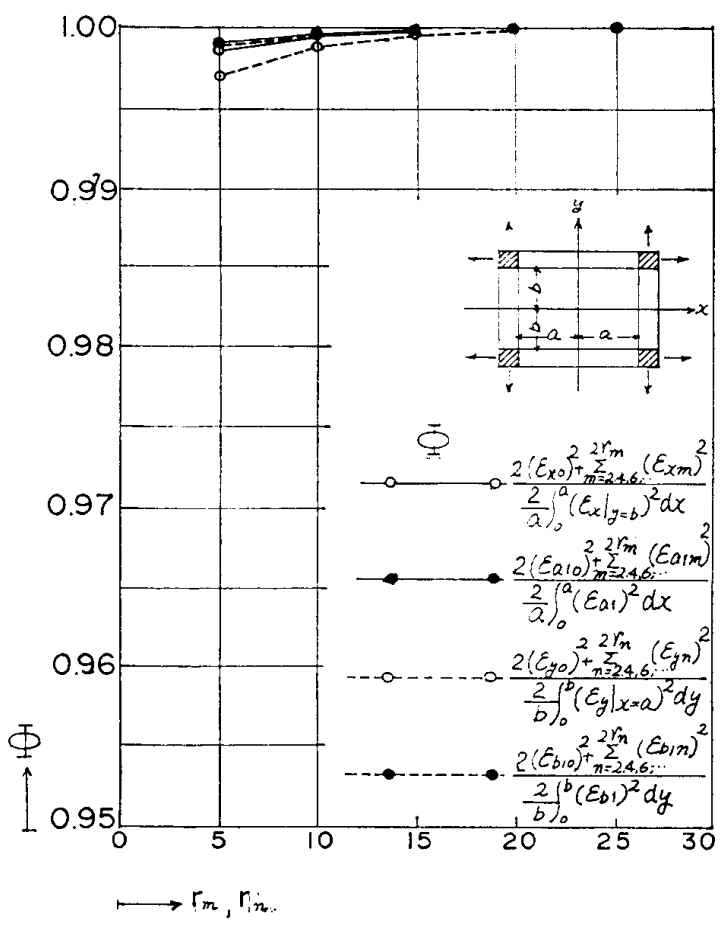

Fig. 5.13 b Convergence of the means of the squares of the errors by expanding the unit elongations parallel to and on the boundaries between the wall and frame into the Fourier series

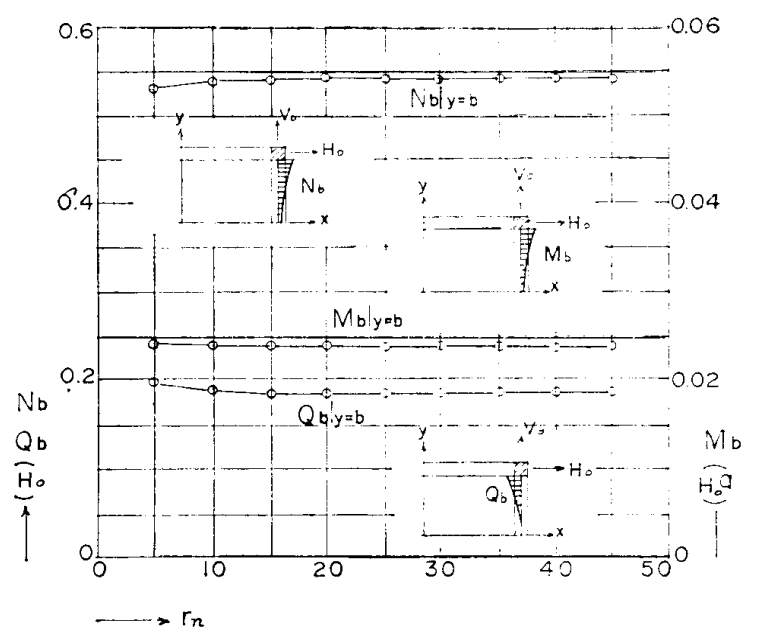

Fig. $5.14 \mathrm{~b}$ Convergence and number of the terms of the Fourier series with respect to the bending moment $\left.M_{b}\right|_{y=c}$, the shearing force $\left.Q_{b}\right|_{y=b}$, the axial tensile force $N_{b} ! y=b$ in the column 
In Figs. 5.15, the conditions of the convergence with regard to the displacements at the corner of the frame are shown.

\section{Conclusions}

The elements (stresses, displacements, etc.) which are derived by integrating the elements (unit stresses, unit elongations) which are used for the continuity conditions on the boundaries between the wall and frame, are obtained with the accurate results when the calcurating are performed with the ten terms of the Fourier series. The values of the stresses and displacements for five and for ten terms differ slightly (two per cents).

The mean squares of the errors by the patial sums in the Fourier expansion are less than two per cents with respect to the elements (unit stresses,

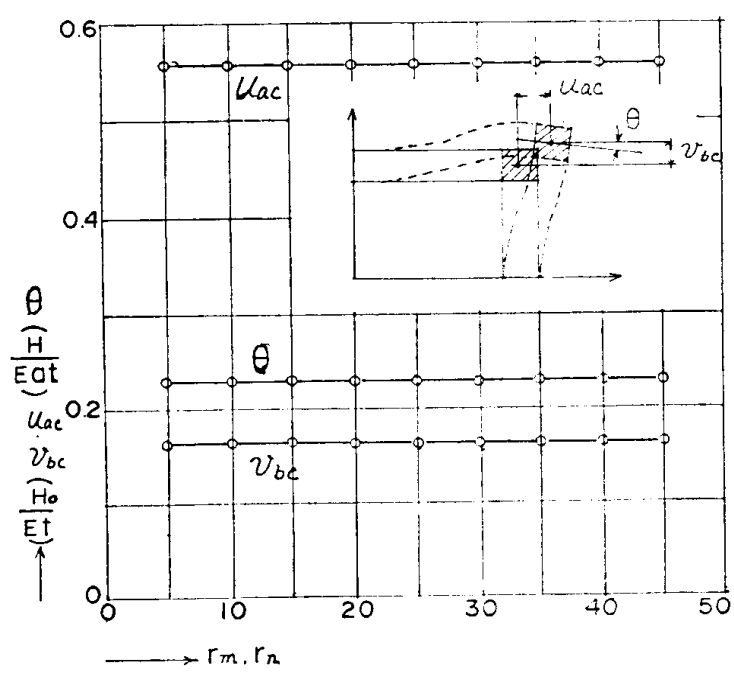

Fig. 5.15 Convergence and number of the terms of the Fourier series with respect to the displacements $U_{a c}, V_{b c}$, at the corner of the frame unit elongations) which are calcurated with the twenty terms of the Fourier series.

The author showed the relations of the convergence and the terms of the numbers of the Fourie series with respect to the analyses of the shear wall I and II. It seems unnecessary to investigate the relations of the convergence and terms of the number of the Fourier series with respect to the shear wall III, because the shear wall III is the conbination of the shear wall I and II.

\section{REFERENCES}

1) Masahide Tomii, Ikuo Tokuhiro, Elastic Analysis of Shear Walls Loaded Antimetrically with regard to their Longitudinal and Transversal Center Lines

Part I Airy's Stress Function, Stresses, Displacements, Etc.

Transactions of the Architectural Institute of Japan (T.A.I.J.), No. 160, June 1968.

Part II Equations for Conditions which are Necessary to Define the Unknown Coefficients, and Numerical Results of an Example

T.A.I.J., No. 161, July 1968.

2) Masahide Tomii, Ikuo Tokuhiro, Elastic Analysis of Shear Walls Loaded Symmetrically with regard to their Longitudinal and Transversal Center Lines

Part I Airy's Stress Function, Stresses, Displacements, Etc.

T.A.I.J., No. 162, Aug. 1968.

Part II Equations for Conditions which are Necessary to Define the Unknown Coefficients, and Numerical Results of an Example

T.A.I.J., No. 163, Sep. 1968.

3) Masahide Tomii, Ikuo Tokuhiro, Elastic Analysis of Shear Walls Loaded Antimetrically with regard to their Longitudinal Center Line and Symmetrically with regard to their Transversal Center Line

Part I Airy's Stress Function, Stresses, Displacements, Etc.

T.A.I.J., No. 165, Oct. 1968.

Part II Equations for Conditions which are Necessary to Define the Unknown Coefficients and Unknown Factor

T.A.I.J., No. 166, Dec. 1968.

Part III Numerical Results of an Example

T.A.I.J., No. 167, Jan. 1969. 


\section{種々な外力を受ける耐震壁の弾性解析における \\ フーリエ 級 数 解 の 収 斂*}

\section{序}

著者と富井政英博士はすでに“エアリ一の応力関数を 用いた耐震壁の弾性解析”を発表してある ${ }^{1) \sim 3) 。 こ れ ら ~}$ の灾力関数注全て三角関数と双曲線関数からなる級数式 と代数型の多項式を併用した応力関数を用いて解析して ある。

さらにこの応力関数から得ら机る応力, 変形などの式 はフーリエ展開されていることからこれらの数值は近似 的なもの之なっている。本論は, これらの解析を耐震壁 に応用するのに先立ってまず計算された数值の誤差につ いて検討を行ならものである。

また作用する外少を

I 縦横軸汇関しともに逆対称な外力

II 縦横軹に関しともに対称な外力

III 緃軸に関し逆対称で，横軸に関し対称な外力 に分解し，これらの外力が作用する耐震壁を耐震壁 I, II，III と㖟えだ。解析は全て外力の逆対称, あるいは対 称条件を考慮して耐震壁の 4 分の 1 部分 $(x \geqq 0, y \geqq 0)$ について解析してある。

既報 ${ }^{1), 2}$ 亿耐震壁の壁板と付帯ラーメンの境界上の連 続条件のたて方について詳述してあるが，以下にその概 略を述べる。

壁板上はり抢よび壁板と柱の各境界において連続条件 を満足している四要素（せん断応力, 垂直応力, 境界楾 に平行なさずみ度，垂直変位）があった。壁板の周辺に おける.上記四要素のうちの二要素（せん断応力, 垂直変 位）を付帯ラーメンに与え，付帯ラーメンに関する残り の二要素を算定し，これらを壁板の当該要素との間に連 続条件式在た大心。

この連況条件式は有限項のフーリエ展開によって各要 素のフーリ二倸数を等しく置くといら方法によってたて られているのであるから，連続条件は完全には成立しな いことになり，この展開誤差は他の要素 (応力, 変形) にも波及する。本論で注酎震壁【の解析》におけるフー

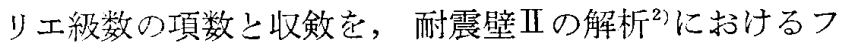
一リエ級数の項数と収斂をそれぞれ

* 本論文の概要は, 日本建築学会大会 (昭和 47 年九州大会) において発表した。

** 九州芸衍工科大学助教授

（昭和 48 年 5 月 16 日本稿受理・封諭期限昭和 48 年 12 月㷊日）
正会員徳広育夫**

に示す。

本論で採用してある耐震壁の形状，断面は図一 5.1 に 示してあり，既報 ${ }^{13}$ (3)の数值計算例で用いた耐震壁と同 じ形状，断面である。

また既報の数值計算例に扔いては，フーリ工級数の項 数を 10 項 $\left(r_{m}, r_{n}=10\right)$ で計算したときの，壁板内お よび付帯ラーメンの応力分布, 変形などを詳細に示して ある。

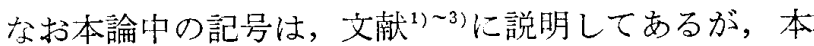
論で始めて出てくる所で説明した。

$\S 5.1 x, y$ 軸に関してそれぞれ逆対称な外力が作用 する場合（図一5.2）の耐震壁の弾性解析にお けるフーリエ級数の項数と収㪘

壁板と付帯ラーメンの境界上の連続条件

A. 壁板の垂直応力 $\left.t \sigma_{y}\right|_{y=b}$ およびはりの垂㨁灾力 $w_{a 1}$ をそれぞれ $\sin \xi_{m}$ に関するフーリエ級数に $5.1 \mathrm{a}$, $5.2 \mathrm{a}$ 式のように展開し，それぞれの式の右辺を等しく 置く之壁板とはりの境界上の垂直応力の連続条件式が $m=1,3,5, \cdots$ の数 $r_{m}$ 個だけ $5.3 \mathrm{a}$ 式のように作られ る。

B. 壁板の垂值応力 $\left.t \sigma_{x}\right|_{x=a}$ および柱の垂直応力 $w_{b_{1}}$ をそれぞれ $\sin \eta_{n}$ に関するフーリエ級数に $5.1 \mathrm{~b}, 5.2 \mathrm{~b}$ 式のように展開し, それぞれの式の右辺を等しく置くと 壁板と柱の境界.上の 垂直応力の 連続条件式が $n=1,3$, $5, \cdots$ の数 $r_{n}$ 個だけ $5.3 \mathrm{~b}$ 式のように作られる。

C. 壁板の境界線方向ひずみ度 $\left.\varepsilon_{x}\right|_{y=b}$ およびはりの 境界線方向ひずみ度 $\varepsilon_{a 1}$ をそれぞれ $\sin \xi_{m}$ に関するフ ーリエ級数に $5.4 \mathrm{a}, 5.5 \mathrm{a}$ 式のように展開し，それぞれ の式の右辺を等しく置くと壁板とはりの境界上の境界線 方向ひずみ度の連続条件式が $m=1,3,5, \cdots$ の数 $r_{m}$ 個 だけ $5.6 \mathrm{a}$ 式のように作られる。

D. 壁板の境界線方向ひずみ度 $\left.\varepsilon_{y}\right|_{x=a}$ および柱の境 界線方向ひずみ度 $\varepsilon_{b_{1}}$ をそれぞれ $\sin \eta_{n}$ に関するフーリ 工級数に $5.4 \mathrm{a}, 5.5 \mathrm{a}$ 式の上うに展開し, それぞれの式 の右辺を等しく置くと壁板とはりの境界上の境界線方向 ひずみ度の連続条件式が $n=1,3,5, \cdots$ の数 $r_{n}$ 個だけ $5.6 \mathrm{~b}$ 式のように作られる。

以上の壁板と付帯ラーメンの垂直応力 $(5.1 \mathrm{a} \sim 5.2 \mathrm{~b}$ 式の左辺)の連続条件をフーリ工級数の項数 $r_{m}=r_{n}=5$, 
20,45 についてそれぞれ図一 $5.3 \mathrm{a}, 5.4 \mathrm{a}, 5.5 \mathrm{a}$ に示し， 壁板と付帯ラーメンの境界上の境界線方向ひずみ度 $(5.4$ $\mathrm{a} \sim 5.5 \mathrm{~b}$ 式の左辺) の連続条件をフーリエ級数の項数 $r_{m}=r_{n}=5,20,45$ についてそれぞれ 図-5.3 b, $5.4 \mathrm{~b}$, $5.5 \mathrm{~b}$ に示してある。

フーリエ展開における誤差を検討するために，有限フ ーリエ展開誤差の 2 乗平均を Bessel の不等式で $5.7 \mathrm{a}$ $\sim 5.10 \mathrm{~b}$ 式のように示し, 垂直応力のフーリエ展開誤 差を図一5.6a に，境界線方向ひずみ度のフーリエ展開 誤差を図一 $5.6 \mathrm{~b}$ に示した。図一 $5.7 \mathrm{a}, 5.7 \mathrm{~b}$ にははり および柱の応力 $(M, N, Q)$ の収㪘状態を図一 5.8 には 付帯ラーメンの変位の収㪘状態を示した。

$\$ 5.2 x, y$ 軸に関してそれぞれ対称な外力が作用す る場合（図一5.9）の耐震壁の弾性解析におけ るフーリエ級数の項数と収㪘

壁板と付帯ラーメンの境界.上の連続条件

A. 壁板の垂直応力 $\left.t \sigma_{y}\right|_{y=b}$ およびはりの垂直応力 $w_{a_{1}}$ をそれぞれ $\cos \xi_{m}$ に関するフーリエ級数に $5.11 \mathrm{a}$, $5.12 \mathrm{a}$ 式のように展開し, それぞれの式の右辺を等しく 置くと, 壁板とはりの境界上の垂直応力の連続条件式が $m=2,4,6, \cdots$ の数 $r_{m}$ 個と定数項を等值する条件式 1 個，合計 $r_{m}+1$ 個だけ $5.13 \mathrm{a}$ 式のように作られる。

B. 壁板の重直応力 $\left.t \sigma_{x}\right|_{x=a}$ および柱の垂直志力 $w_{b_{1}}$ をそれぞれ $\cos \eta_{n}$ に関するフーリエ級数に $5.11 \mathrm{~b}, 5.12$ b 式のよらに展開し，それぞれの式の右辺を等しく置く と壁板と柱の境界上の垂直応力の連続条件式が $n=2,4$, $6, \cdots$ の数 $r_{n}$ 個上定数項を等值する条件式 1 個, 合計 $r_{n}+1$ 個だけ $5.13 \mathrm{~b}$ 式のように作られる。

C. 壁板の境界線方向ひずみ度 $\left.\varepsilon_{x}\right|_{y=b}$ およびはりの 境界線方向ひずみ度 $\varepsilon_{a_{1}}$ をそれぞれ $\cos \xi_{m}$ に関するフ 一リエ級数に $5.14 \mathrm{a}, 5.15 \mathrm{a}$ 式のように展開し, それぞ れの式の右辺を等しく置くと壁板とはりの境界線方向ひ ずみ度の連続条件式が $m=2,4,6, \cdots の$ 数 $r_{m}$ 個之定数 項を等值する条件式 1 個, 合計 $r_{m}+1$ 個だけ $5.16 \mathrm{a}$ 式 のように作られる。

D. 壁板の境界線方向ひずみ管 $\left.\varepsilon_{y}\right|_{x=a}$ および柱の境
界線方向ひずみ度 $\varepsilon_{b_{1}}$ をそれぞれ $\cos \eta_{n}$ に関するフー リエ級数に $5.14 \mathrm{~b}, 5.15 \mathrm{~b}$ 式のように展開し, それぞ れの式の右辺を等しく置くと壁板と柱の境界線方向ひず 夕度の連続条件式が $n=2,4,6, \cdots$ の数 $r_{n}$ 個上定数項 を等值する条件式 1 個, 合計 $r_{n}+1$ 個だけ $5.16 \mathrm{~b}$ 式の ように作られる。

以上の壁板と付帯ラーメンの垂直応力 $(5.11 \mathrm{a} \sim 5.12 \mathrm{~b}$ 式の左辺）の連続条件をフーリエ級数の項数 $r_{m}=r_{n}=$ $5,20,45$ についてそれぞれ図-5.10a，5.11 a , 5.12 a に示し，壁板と付帯ラーメンの境界上の境界線方向ひず

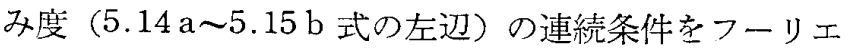
級数の項数 $r_{m}=r_{n}=5,20,45$ についてそれぎれ図一 $5.10 \mathrm{~b}, 5.11 \mathrm{~b}, 5.12 \mathrm{~b}$ に示した。

フーリエ展開における誤差を検討するために，有限フ ーリエ展開誤差の 2 乗平均を Bessel の不等式で $5.17 \mathrm{a}$ 〜 $5.20 \mathrm{~b}$ 式のように示し, 重直心力のフーリエ展開誤 差を図 $5.13 \mathrm{a} に$ ，境界線方向ひずみ度のフーリエ展開 誤差を図 $5.13 \mathrm{~b}$ に示した。図 $5.14 \mathrm{a}$ ，図 $5.14 \mathrm{~b}$ には りおよび柱の応力 $(M, N, Q)$ の収㪘状態，図-5.15 には付带ラーメンの節点の変位 $\left(u_{a c}, v_{b c}, \theta\right)$ の収㪘状 態を示した。

\section{$\$ 5.3$ 結 論}

壁板と付帯ラーメンの境界上で連続条件に用いた要素 （垂直応力，境界線方向ひずみ度）を積分することによ って求められる要素 (はりの応力, 耐震壁の変形) はフ ーリエ級数の項数を 10 項とって計算寸ればかなりの精 度 ( 3 桁) で得られる。なおフーリ工称数の項数が 5 項 と 10 項の場合の応力 $(M, N, Q$, 変形などは 45 項の 㤼合と比べて $2 \%$ 程度の差がある。連続条件に用いた要 素（垂淔応力, 境界線方向ひずみ度）に関する有限項の フーリエ展開による部分和の誤差の 2 乗平均はフーリエ 展開項数が 20 項のとき $2 \%$ 以内となる。

以上は耐震壁 I, II についてのフーリ二級数の項数 と収㪘であるが，耐震壁 III は耐震壁 I，II の組合せと 考えられるので検討を琶しないと思われる。 


\section{ELASTIC-PLASTIC ANALYSIS OF THREE-DIMENSIONAL CONCRETE STRUCTURE BY THE FINITE ELEMENT METHOD (APPLICATION TO AXYSIMMETRIC PRESTRESSED CONCRETE PRESSURE VESSEL)}

by OSAMU ISOBATA, Research Laboratory of Shimizu Construc tion Co., LTD, Member of A.I.J.

An orthotropic elasto-plastic material in which elastic modulus and Poisson's ratio may be defined based on those of uniaxial stress-strain characteristics is assumed for the concrete.

Three-dimensional stress-strain relationship matrix $\left[D_{e p}\right]$ is derived from that of the anisotropic elastic body and expressed in the form;

$$
\left[D_{e p}\right]=\left[A_{p}\right]^{T}\left\{[D]+\left[H_{p}\right]\right\}\left[A_{p}\right]
$$

Where $[D]$ is the stress-strain relationship matrix of the homogineous elastic body. $\left[A_{p}\right]$ and $\left[H_{p}\right]$ are related to the changes of elastic tangent modulus and Poisson's ratio respectively.

The element stiffness matrix may be obtained by using $\left[D_{e p}\right]$ instead of $[D]$.

As an application of this method to the axisymmetric body, ultimate pressure analysis of the prestressed concrete pressure vessel is described by using the technic of elastic stress analysis by the F.E.M..

In the numerical procedure of the computor program, it is assumed that when a principal tensile strain exceeds the critical tensile strain and tensile stress remains in the same direction, the element is able to crack and stresses on the crack are released.

When a compressive strain exceeds the critical compressive strain the element stiffness is treated to fail completely.

The numerical results are discussed with the $1 / 40$ th scale model test results, and it is assured that the method is valid to consider the behaviors of the PCPV beyond the elastic range.

U.D.C. $539.37: 69.022: 699.84$

\section{CONVERGENCE OF FOURIER SERIES SOLUTIONS IN THE ELASTIC ANALYSES OF THE SHEAR WALLS SUBJECTED TO THE VARIOUS EXTERNAL PLANE FORCES}

(See Page 15)

by IKUO TOKUHIRO, Assistant Prof. of Kyushu Institute of Design, Member of A.I.J.

\section{TENTATIVE PROPOSAL FOR DYNAMIC EARTHQUAKE RESISTANT DESIGN OF TALL REINFORCED CONCRETE CHIMNEYS}

by KAZUYOSHI UCHIDA, Research Engineer of Muto Institute of Structural Mechanics, Inc. Member of A.I.J.

In 1966 the author found through the dynamic response analysis that tall reinforced concrete chimneys designed by the Japanese seismic code are very strong in their bottom portion but extremely weak in their upper portion. Then in order to renew this absurdity, the author tried to establish a tentative proposal of the earthquake resistant design method on which effect of the dynamic behavior is reflected.

Namely, such parameters as chimney heights, chimney proportions, foundation conditions, damping assumptions and earthquake waves are selected for investigating the vibration characteristics of tall chimneys by means of the direct earthquake response analysis. Thus, a tentative method for manual calculation of dynamic earthquake forces acting on chimneys is proposed on the basis of the analyzed vibration characteristics.

The main formulas recommended in this paper are as follows :

1) Determination of chimney proportion

2) First natural period

3) Coefficients of both base shear and base overturning moment

4) Distribution of both shear and bending moment along chimney height 